\title{
SRY gene mutation in Rattus norvegicus induced by various time exposure of mobile phone
}

\author{
ARNI AMIR ${ }^{1, \boldsymbol{v}}$, ERYATI DARWIN",v, AHMAD ZULVA JUNIARTO ${ }^{2}$ \\ ${ }^{1}$ Department of Biology, Faculty of Medicine, Universitas Andalas. Jl. Perintis Kemerdekaan, Jati Baru, Padang Timur, Padang 25129, West Sumatra, \\ Indonesia. Tel./fax.: +62-751-30706, ”email: arniamir@med.unand.ac.id \\ ${ }^{2}$ Department of Histology, Faculty of Medicine, Universitas Andalas. J1. Perintis Kemerdekaan, Jati Baru, Padang Timur, Padang 25129, West Sumatra, \\ Indonesia. Tel./fax.: +62-751-30706, "email: eryatidarwin@fk.unand.ac.id
}

Manuscript received: 14 October 2017. Revision accepted: 13 April 2018

\begin{abstract}
Amir A, Darwin E, Juniarto AZ. 2018. Effects of mobile phone exposure to SRY gene in Rattus norvegicus. Biodiversitas 19: 802-808. Mobile phones are low power radio devices, which transmit and receive radio frequency radiation in the microwave spectrum ranging from $900-1,800 \mathrm{MHz}$ through an antenna used closely to the user's head. Radiation destructs living tissue by altering structure of cell and damaging the DNA, damaging of genetic material in reproductive cells causes mutations and affecting to the next generation. The genetic database of mutation in human SRY gene has been collected and had the correlation between mutation and the occurrence of sex development disorder (translocation). However, the study focussing on SRY gene mutation to the exposure of mobile phone has not been studied, yet. This study was aimed to investigate the effect of various time exposure of mobile phone toward the characteristic of SRY gene fragments in Rattus norvegicus. Experimental research with randomized post test only control design was conducted on 20 Wistar aged 2-3 months with 200-250 grams of weight. Samples were divided into four groups, with three treatment groups based on radiation exposure time (30,60, and 90 minutes), and one group as control group (without treatment) for 60 days. Following exposure, DNA was isolated from blood of rat, and amplified with a pair of SRY primer set. Positive DNA of SRY gene was assessed by sequencing the genes and determining the mutations. There were three single nucleotide polymorphism (SNP) of SRY gene in histidine 38 glutamine, $(\mathrm{CAT}>\mathrm{CAG})$, proline 76 threonine $(\mathrm{CCT}>\mathrm{ACT})$ and leucine 102 leucine $(\mathrm{CTG}>\mathrm{TTG})$. Long duration of radiation exposure for 90 minutes increased the risk of SRY gene mutation. $\square$
\end{abstract}

Keywords: Mobile phone, SRY Gene, SNP, radiation exposure

\section{INTRODUCTION}

The use of mobile phone is estimated to reach five billion users (ITU 2010). Most of mobile phone users do not aware of the dangers of the electromagnetic radiation from the device, which can affect the human health. This is because the lack of information on how mobile phone has an effect on human health (Uddin and Ferdous 2005).

Mobile phones are low power radio devices that transmit and receive radio frequency radiation in the microwave spectrum ranging from $900-1,800 \mathrm{MHz}$ (Figure 1). These devices may be classified as analog of advanced mobile phone system (AMPS). Various types of analog and digital cellular phones are used across the globe. Analog telephones transmit modulations of the amplitude or frequency of electromagnetic waves, which are transmitted continuously. On the other hand, the digital telephones transmit data in series of pulses or fast bursts. The digital systems allow simultaneous transmission of messages from different users in the same frequency resulting in the increased capacity of the transmission channels. Digital systems have recently replaced analog (Talib et al. 2010).

The type of field exposure of radio frequency electromagnetic radiation (RFEMR) is generally used in communication via mobile phone. The exposure of RFEMR has the a broad range of genotoxic effects i.e. the occurrence of aneuploidy, sister chromatid exchange, impaired intrachromosomal recombination, and the increase of nuclei formation in mammalian cells (Sykes et al. 2001; d'Ambrosio et al. 2002; Tice et al. 2002; Mashevich et al. 2003). Radiation destructs living tissue by altering the structure of cell and damaging DNA. The damage of DNA depends on the type of radiation, energy level and amount of absorbed radiation (Swamardika 2009). The damage of genetic material in reproductive cells causes mutations, which can be passed through to the next generation (Canadian Nuclear Safety Commission 2012). The SRY/Sry gene is one of genes, which take responsible to determine the chromosome Y-testis. This gene is the key of sexual reproduction, which can be used as the engine for genetic recombination and natural selection. SRY determines the axis point of $\mathrm{XY}$ sex development in mammalian embryos by stimulating the testes differentiation rather than the ovaries from the genital ridges of the embryonic anlagen of gonad (Koopman et al. 1991, The male sex differentiation of the embryo occurs when testes have formed and it is promoted by hormones produced by the Leydig cells. On the other hand, in embryos where SRY is absent or non-functional, the genital ridges will develop ovaries followed by female sex differentiation (Hawkins et al. 1992; Kato et al. 2013). 


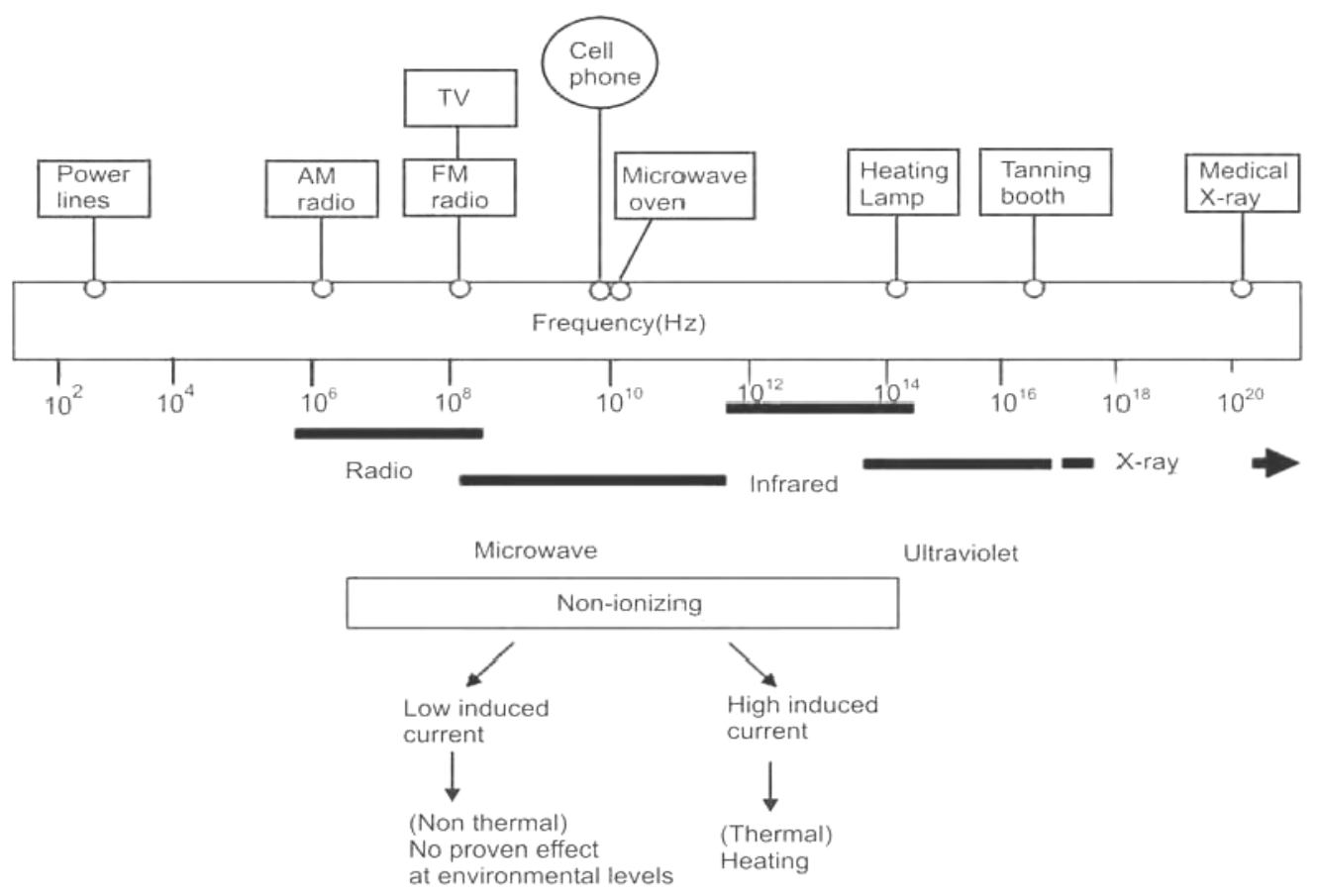

Figure 1. In the term of electromagnetic spectrum, cell phones fall between microwave ovens and TV transmitter. Such radiation, through non-ionizing, can reduce biologically significant effect (Behari 2010)

In mammalian, SRY gene present on the $Y$ chromosome providing the expression of males. Mutations in SRY have occured in approximately $15-20 \%$ of 46 sexual cases in which XY chromosomes have complete or partial gonadal dysgenesis. The genetic database of mutation in human SRY gene has been collected over past 25 years and it has been correlated with one of mutation types such as the occurrence of sex development disorder (translocation) (Knower et al. 2011). The impaired function of SRY causes gonadal dysgenesis leading to the development of a female somatic phenotype (Phillips et al. 2006). Study which concerns about SRY mutation because of the exposure of mobile phone has been limited. Therefore, this study investigated the effect of various time exposure of mobile phone toward the characteristics of SRY gene fragments in Rattus novergicus.

\section{MATERIALS AND METHODS}

\section{Procedures}

\section{Animal handling and treatment}

This study was conducted from June to September 2017, with Randomized Post Test Only Control design. Experimental procedures were done at Animal House Biomedical Laboratory, Faculty of Medicine, Andalas University. The house, monitor and treatment of animal were in accordance with institutional animal ethics requirements. Food and water were provided ad libitum. Once acclimatized, groups of rats were randomly placed into standard plastic mouse cages.
Samples consisted of 20 white rats Rattus novergicus, male, age 2-3 months, and 200-250 g of body weight. Samples divided into four groups, one control group, and three treatment groups. In treatment groups, rats were exposed to radiation for 30, 60, and 90 minutes, and no treatment applied in control group. After one cycle of spermatogenesis occurred, testes and cauda epididymides were dissected, and blood collection was done for examination of SRY gene mutation.

\section{Irradiation procedures}

For each experiment, five rats were placed in a container plastic box $(55 \times 40 \times 30 \mathrm{~cm})$ for 60 days (one cycle of spermatogenesis). Irradiation was performed at 09.00 pm every day because rat is nocturnal. Each box was hung up four cell phones; two in left especially for only receiving calls, and two in right side especially for outgoing call. Daily measurements included room temperature and humidity readings. The rats were also weighed and inspected for clinical signs of illness daily. After the irradiation schedule based on one cycle of spermatogenesis, rats were killed by $\mathrm{CO}_{2}$ asphyxiation, and blood was collected.

\section{Isolation of DNA}

DNA was isolated using PureLink DNA isolation kit Genomic DNA Mini kit (Invitrogen, USA). The isolation procedure was carried out according to the manufacturer's instructions. The result of genomic DNA isolation was visualized by electrophoresis $1.5 \%$ agarose gel and DNA concentration was calculated by Nano Drop (Thermo Fisher, USA), which was then stored at $-20^{\circ} \mathrm{C}$. 


\section{SRY gene mutation}

Positive DNA was amplified with a set of forward (5'TTTGGGAGCAGTGACAGTTG-3') and reverse (5'GTGGACAGTAAGTAGGTTAGCTG-3) SRY primers. A pair of primer set for detecting SRY gene mutation was designed from SRY gene sequences in GenBank database (NCBI Accession No.NC 024475.1) with Geneious software v7.0 (Biomatters L $\overline{t d}$, Auckland, New Zealand). Primers were synthesized by Integrated DNA Technologies (IDT), Singapore (Figure 2). Composition of SRY PCR reaction with total volume of $25 \mu \mathrm{l}$ consisted of $12.5 \mu \mathrm{l}$ GoTaq Green Master Mix (Promega, USA), $2.5 \mu$ I DNA genomic, $0.4 \mu \mathrm{M}$ SRY-F primer and $0.4 \mu \mathrm{M}$ SRY-R primer. Amplification of SRY gene was performed followed by: initial denaturation at $95^{\circ} \mathrm{C}$ for $5 \mathrm{~min}$, followed by 35 cycles comprised with denaturation at $95^{\circ} \mathrm{C}$ for 30 seconds, annealing at $62^{\circ} \mathrm{C}$ for 30 seconds, and elongation at $72^{\circ} \mathrm{C}$ for 50 seconds, and final elongation at $72^{\circ} \mathrm{C}$ for 5 minutes.

To ensure the specificity of PCR reactions, PCR products were also visualized after electrophoreses through a 1.5\% agarose gel and stained with DNA GelRed.

PCR product of SRY gene was purified with Na-acetate and cooling ethanol absolute. $20 \mu \mathrm{l}$ of pure SRY PCR product was sent for sequencing analysis with Sanger method in Macrogen, South Korea.

Data of sequencing was analyzed with Geneious Software v7.0 (Biomatters Ltd, Auckland, New Zealand). Multiple alignments were performed by comparing the result of SRY gene sequences with SRY gene database (NC_024475.1) for genotyping analysis.

\section{Data analysis}

The sequence of DNA was checked by online software BioEdit v7.0.5 (Ibis Therapeutics, Carlsbad). The genotyping of allele was identified by sequence alignments analysis with Geneious Software v7.0 (Biomatters Ltd, Auckland, New Zealand). Percentage of each genotype was determined by the frequency of allele mutation in each locus.

\section{RESULTS AND DISCUSSION}

\section{Isolation of genomic DNA}

A total of 20 sample of blood rat was isolated after irradiation performences. The result of DNA isolation visualized in electrophoresis showed that DNA had a good quality (Figure 3). The size of SRY gene after electrophoresis was estimated around 500bp (Figure 4). However, after the sequencing process, the size of SRY gene was longer (595bp). SRY gene has a pseudogene which may be amplified with SRY primer, caused the increased size of gene.

The result of sequencing showed three Single Nucleotide Polymorphism (SNP), detected in position Histidine38Glutamine $(\mathrm{CAT}>\mathrm{CA} \underline{\mathrm{G}})$, Proline 76Threonine $(\underline{\mathrm{CCT}}>\underline{\mathrm{ACT}})$, and Leucine 102 Leucine $(\underline{\mathrm{CTG}}>\underline{\mathrm{TTG}})$ (Table 1). There were four novel genotypes found in SRY gene; TG and $\mathrm{GG}$ in histidine38glutamine, $\mathrm{CA}$ in proline76threonine, and CT in leucine102leucine. Most of genotype was heterozygote mutant, and one genotype was homozygote mutant. Point mutation in three genotypes of SRY gene (TG, GG, and CA) caused the alteration of amino acid; TG, GG altered histidine to glutamine, and CA altered proline to threonine.

\section{SRY mutation in His38GIn location}

The mutation of three genotypes were identified in His 38 Gln location i.e TT, TG, and GG mutation. 15 out of 20 samples also showed point mutation at TG allele position and five samples in GG allele position (Table 1). The TG allele was found both in control group and in treated groups (30 and 60 minutes radiation exposure), and GG allele was found in treated group with 90 minutes of radiation exposure. TT is the wild-type allele, while TG is a heterozygote mutant, and AA is a homozygote mutant. TG was predominantly found in His $38 \mathrm{Gln}$ location ( $\mathrm{f}=15$, $75 \%, \mathrm{n}=5,0 \mathrm{~min} ; \mathrm{n}=5,30 \mathrm{~min} ; \mathrm{n}=5,60 \mathrm{~min})$, the second one was GG ( $\mathrm{f}=5,25 \%, \mathrm{n}=5,90 \mathrm{~min})$, while TT did not find in His38Gln location $(\mathrm{f}=0,0 \%)$. The mutation in His38Gln location (CA $\underline{T}>\mathrm{CAG})$ altered the amino acid of histidine to glutamine.

\section{SRY mutation in Pro76Thr location}

Point mutation also occurred in Pro76Thr, but only one allele was detected. There are three alleles in Pro76Thr; CC was a wild-type allele, CA was a heterozygote mutant, and AA was a homozygote mutant. CA was found in all samples $(f=20,100 \%, n=5,0 \min ; n=5,30 \min ; n=5,60$ min; $n=5,90 \mathrm{~min}$ ), but $\mathrm{CC}$ and AA allele were not found in this location (Table 2). The mutation in Pro76Thr location $(\underline{\mathrm{CCT}}>\underline{\mathrm{ACT}})$, altered the amino acid of proline to threonine.

Table 1. Genotype alleles of His38Gln in SRY gene

\begin{tabular}{lccccc}
\hline & \multirow{2}{*}{ Sample } & No. of & \multicolumn{3}{c}{ Genotypes } \\
\cline { 4 - 6 } & & sample & TT & TG & GG \\
\hline His38Gln & K1-5 & 5 & 0 & 5 & 0 \\
(CAT $>$ & P1.1-5 & 5 & 0 & 5 & 0 \\
CAG) & P2.1-5 & 5 & 0 & 5 & 0 \\
& P3.1-5 & 5 & 0 & 0 & 5 \\
Total & & 20 & 0 & 15 & 5 \\
& & & $0 \%$ & $75 \%$ & $25 \%$
\end{tabular}

Note= K1-5, control group; P1.1-5, 30 min; P2.1-5, 60 min; P3.15,90 min radiation exposure.

Table 2. Genotype alleles of Pro76Thr in SRY gene

\begin{tabular}{lccccc} 
& \multirow{2}{*}{ Site } & $\begin{array}{c}\text { No. of } \\
\text { sample }\end{array}$ & \multicolumn{3}{c}{ Genotypes } \\
\cline { 4 - 6 } & & 5 & 0 & 5 & 0 \\
Pro76Thr & K1-5 & 5 & CA & AA \\
(CCT & P1.1-5 & 5 & 0 & 5 & 0 \\
ACT $)$ & P2.1-5 & 5 & 0 & 5 & 0 \\
& P3.1-5 & 5 & 0 & 5 & 0 \\
Total & & 20 & 0 & 20 & 0 \\
& & & $0 \%$ & $100 \%$ & $0 \%$ \\
\hline
\end{tabular}

Note= K1-5, control group; P1.1-5, 30 min; P2.1-5, 60 min; P3.15,90 min radiation exposure 


\section{SRY mutation in Leu102Leu location}

In Leu102Leu location, the point mutation was detected in CT allele ( $f=20,100 \%, n=5,0 \min ; n=5,30 \min ; n=5$, $60 \mathrm{~min} ; \mathrm{n}=5,90 \mathrm{~min}$ ). The mutation was not found in $\mathrm{CC}$ and TT allele (Table 3). CC was a wild-type allele, while CT was a heterozygote mutant, and TT was a homozygote mutant. The mutation in Leu102Leu location $(\underline{\mathrm{CTG}}>\underline{\mathrm{TTG}})$ did not change the amino acid of leucine.

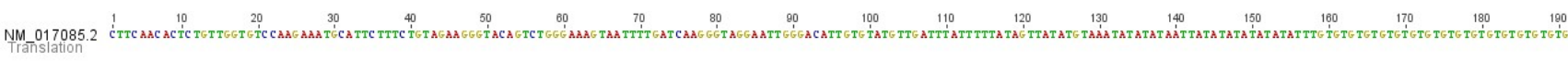

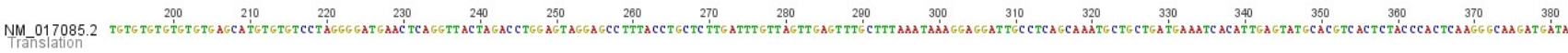

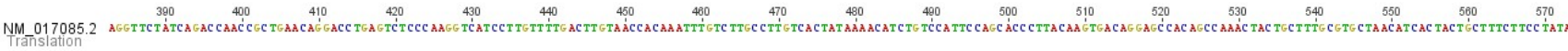

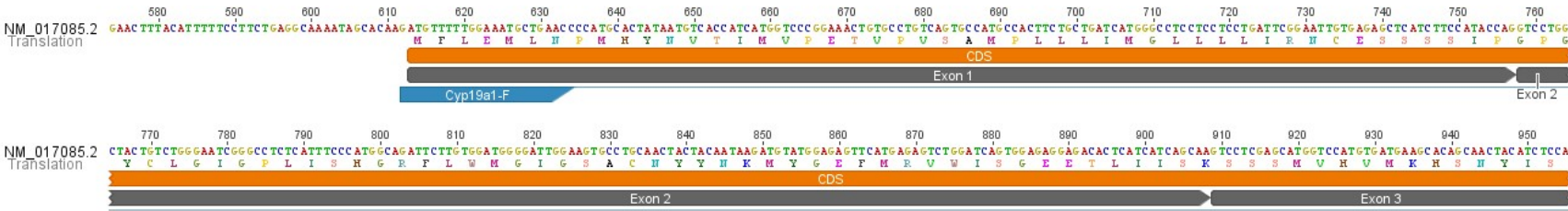

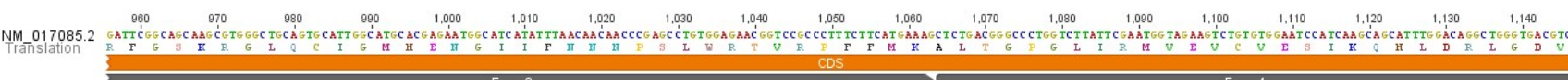

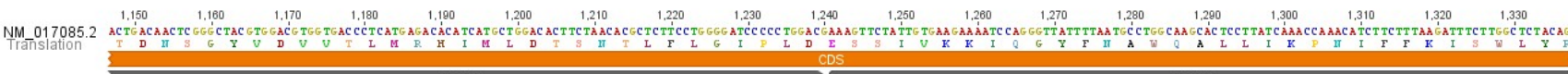

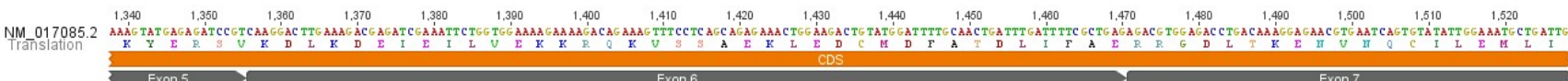

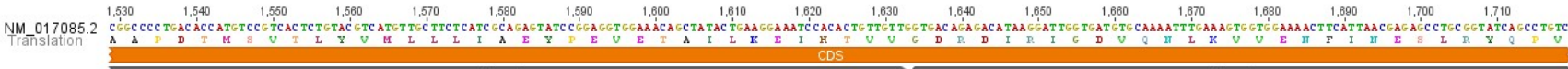

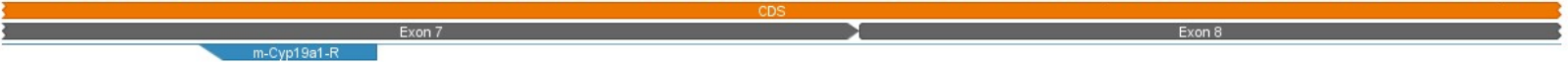

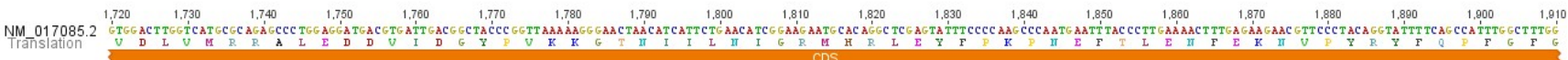
Exon8 Cos

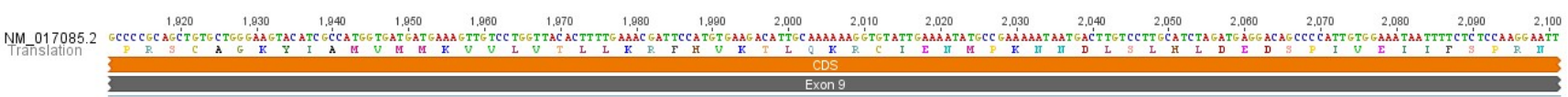

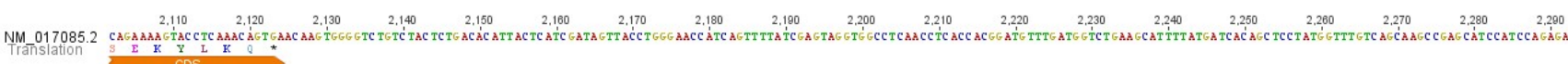
Cyp19a1-R

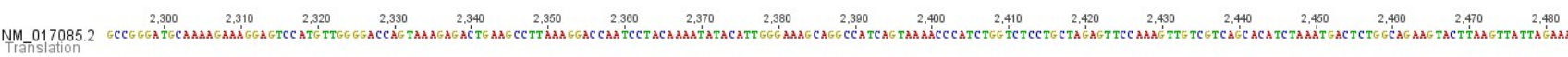
NM M17085.2.

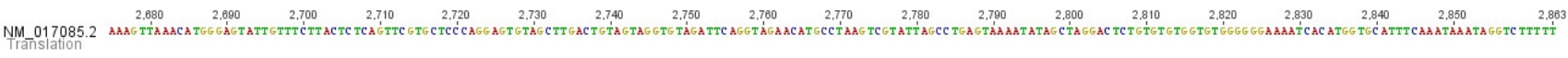




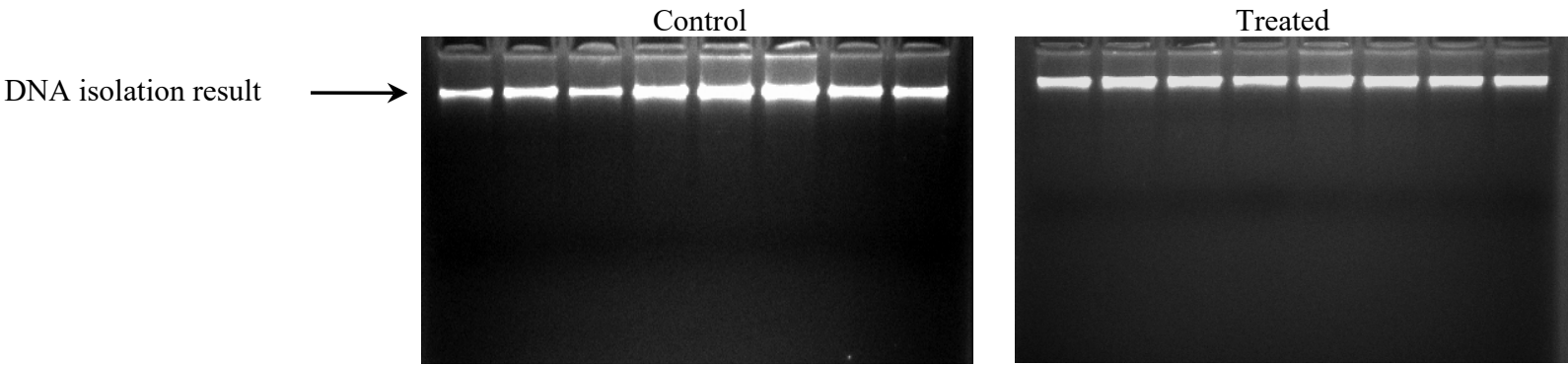

Figure 3. Electrophoresis result of genomic DNA on 1.5\% agarose gel. Positive PCR product of DNA was amplified with SRY primer set

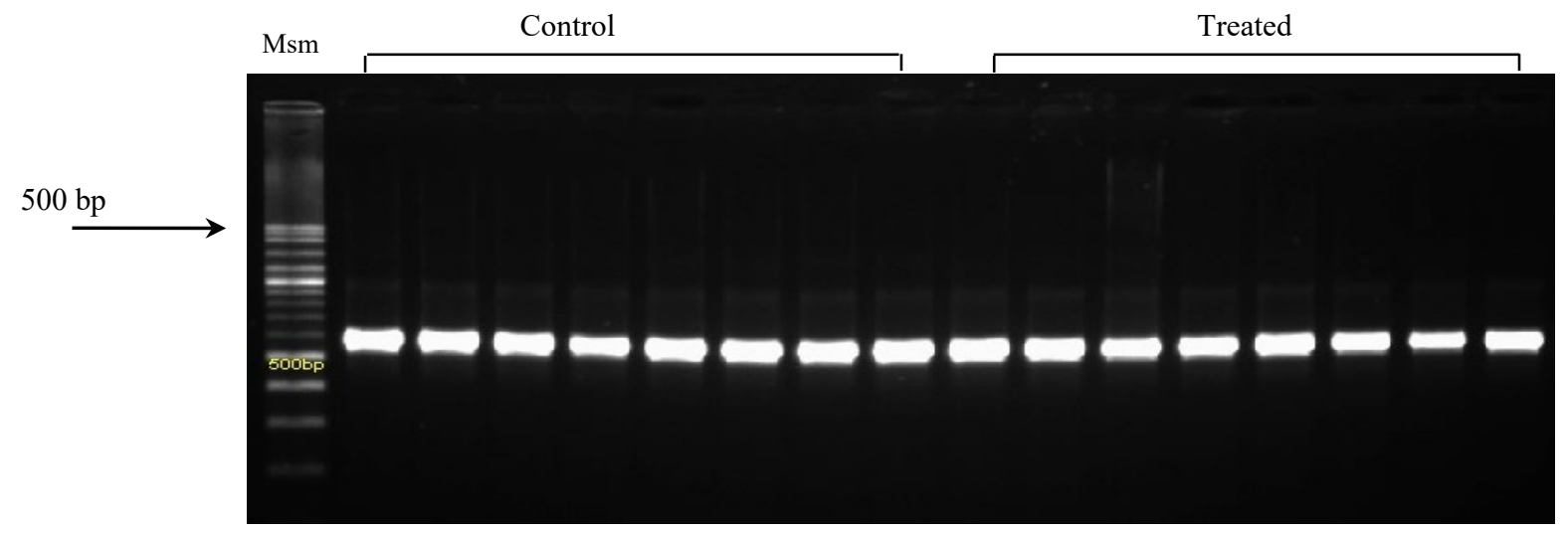

Figure 4. The electrophoresis result of PCR amplification with SRY primers. Each sample showed the good quality of DNA band. Position of band was at 500bp. Representative gels of eight samples from control and treated groups are shown. Msm = molecular size marker

Table 3. Genotype alleles of Leu102Leu in SRY gene

\begin{tabular}{lccccc}
\hline & \multirow{2}{*}{ Site } & No. of & \multicolumn{3}{c}{ Genotypes } \\
\cline { 4 - 6 } & & sample & CC & CT & TT \\
\hline Leu102Leu & K1-5 & 9 & 0 & 5 & 0 \\
(CTG $>$ & P1.1-5 & 8 & 0 & 5 & 0 \\
TTG) & P2.1-5 & 9 & 0 & 5 & 0 \\
& P3.1-5 & 10 & 0 & 5 & 0 \\
Total & & 20 & 0 & 20 & 0 \\
& & & $0 \%$ & $100 \%$ & $0 \%$ \\
\hline
\end{tabular}

Note= K1-5, control group; P1.1-5, 30 min; P2.1-5, 60 min; P3.15,90 min radiation exposure

Three nucleotide polymorphism found in this study was detected in position Histidine38Glutamine (CAT $>$ CAG $)$, Proline76Threonine ( $\underline{\mathrm{CCT}}>\underline{\mathrm{ACT}})$, and Leusine102Leusine (CTG $>$ TTG) both in treated $(30,60,90 \mathrm{~min}$ of radiation exposure) and control group. Two of three mutations showed that the point mutation in two areas of SRY gene had altered the synthesis of amino acid (histidine $>$ glutamine and proline $>$ threonine). These indicated that the radiation exposure of mobile phone for 30,60 , and 90 min in 60 days (one cycle of spermatogenesis) were able to induce the mutation.

The various alterations in human or animal tissue are caused by the partial or comprehensive exposure of radio frequency radiation to the body via mobile phone. (Behari 2010). The effect of radiation elevates the risk of cancer or the occurrence of genetic mutations, and may be inherited to the next generations; or the over exposure of radiation causes severe damage of tissue, and the mortality occurs within a few weeks of exposure (Goodman et al. 1999; CTIA 2003). The silent mutations affect the expression of gene and play a role in different levels with different mechanisms (Sauna et al. 2011). The variation of DNA sequence or nucleotide polymorphisms frequently ensues within a population. Silent polymorphisms (the alteration of nucleotide does not change the translation of amino acid in the encoded protein) increase the attention of researchers in the last decade (Chaney et al. 2015). This kind of polymorphism can produce different effects on gene expression and lead to functional differences of diverse significance. Several recent reviews summarize the effects of such mutations, in particular in relation to human diseases, personalized biomedicine and pharmacogenomics (Chamary et al. 2006; Sauna et al. 2007a,b; Fahraeus et al. 2015).

In this study, the mutation was also found in control group (Table 4). It may be due to the position of container boxes of all group was placed in one room, and probably the radiation of cell phone still affected rats in control group. Sander et al. (1982) revealed that adverse physiological or psychological effects were observed in laboratory studies of people exposed to $50-\mathrm{Hz}$ fields in the range from $2-5 \mathrm{~m}$. Using the phone in areas of good reception also decreases exposure as it allows the phone to transmit in the reduced power (WHO 2014). 
Table 4. Polymorphism in SRY gene after radiation exposure with cell phone

\begin{tabular}{|c|c|c|c|c|c|c|}
\hline \multirow[b]{2}{*}{ Sample } & \multicolumn{2}{|c|}{ Histidine38Glutamine (His38GIn) } & \multicolumn{2}{|c|}{ Proline76Threonine (Pro76Thr) } & \multicolumn{2}{|c|}{ Leucine102Leucine (Leu102Leu) } \\
\hline & CAT $>$ CAG & Phenotype & $\mathbf{C C T}>\mathbf{A C T}$ & Phenotype & CTG $>$ TTG & Phenotype \\
\hline K1 & TG & Heterozygote mutant & $\mathrm{CA}$ & Heterozygote mutant & $\mathrm{CT}$ & Heterozygote mutant \\
\hline $\mathrm{K} 2$ & TG & Heterozygote mutant & CA & Heterozygote mutant & $\mathrm{CT}$ & Heterozygote mutant \\
\hline K3 & TG & Heterozygote mutant & CA & Heterozygote mutant & $\mathrm{CT}$ & Heterozygote mutant \\
\hline K4 & TG & Heterozygote mutant & CA & Heterozygote mutant & $\mathrm{CT}$ & Heterozygote mutant \\
\hline K5 & TG & Heterozygote mutant & CA & Heterozygote mutant & $\mathrm{CT}$ & Heterozygote mutant \\
\hline P1-1 & TG & Heterozygote mutant & CA & Heterozygote mutant & $\mathrm{CT}$ & Heterozygote mutant \\
\hline P1-2 & TG & Heterozygote mutant & CA & Heterozygote mutant & $\mathrm{CT}$ & Heterozygote mutant \\
\hline P1-3 & TG & Heterozygote mutant & $\mathrm{CA}$ & Heterozygote mutant & $\mathrm{CT}$ & Heterozygote mutant \\
\hline P1-4 & TG & Heterozygote mutant & CA & Heterozygote mutant & $\mathrm{CT}$ & Heterozygote mutant \\
\hline P1-5 & TG & Heterozygote mutant & CA & Heterozygote mutant & $\mathrm{CT}$ & Heterozygote mutant \\
\hline P2-1 & TG & Heterozygote mutant & $\mathrm{CA}$ & Heterozygote mutant & $\mathrm{CT}$ & Heterozygote mutant \\
\hline P2-2 & TG & Heterozygote mutant & $\mathrm{CA}$ & Heterozygote mutant & $\mathrm{CT}$ & Heterozygote mutant \\
\hline P2-3 & TG & Heterozygote mutant & CA & Heterozygote mutant & $\mathrm{CT}$ & Heterozygote mutant \\
\hline P2-4 & TG & Heterozygote mutant & $\mathrm{CA}$ & Heterozygote mutant & $\mathrm{CT}$ & Heterozygote mutant \\
\hline P2-5 & TG & Heterozygote mutant & CA & Heterozygote mutant & $\mathrm{CT}$ & Heterozygote mutant \\
\hline P3-1 & GG & Homozygote mutant & $\mathrm{CA}$ & Heterozygote mutant & $\mathrm{CT}$ & Heterozygote mutant \\
\hline P3-2 & GG & Homozygote mutant & $\mathrm{CA}$ & Heterozygote mutant & $\mathrm{CT}$ & Heterozygote mutant \\
\hline P3-3 & GG & Homozygote mutant & $\mathrm{CA}$ & Heterozygote mutant & $\mathrm{CT}$ & Heterozygote mutant \\
\hline P3-4 & GG & Homozygote mutant & $\mathrm{CA}$ & Heterozygote mutant & $\mathrm{CT}$ & Heterozygote mutant \\
\hline P3-5 & GG & Homozygote mutant & CA & Heterozygote mutant & $\mathrm{CT}$ & Heterozygote mutant \\
\hline
\end{tabular}

Note: K1-5, control group; P1.1-5, 30 min; P2.1-5, 60 min; P3.1-5, 90 min radiation exposure

Radiation exposure of mobile phone for 90 minutes to treatment groups, showed that it has impact on the DNA of rat, homozygote mutant that detected in SRY sequence indicated that radiation generated established-genotype in SRY gene.

Mutations in SRY gene result in XY sex reversal and pure gonadal dysgenesis. SRY expression initiates a network of gene activity that transforms the undifferentiated gonad, genital ridge into testis. Mutations in the SRY gene have been considered to account for only $10-15 \%$ of $46, \mathrm{XY}$ gonadal dysgenesis cases, whereas the majority of the remaining cases may have mutation (s) in the SRY regulatory elements or other genes involved in the sex differentiation pathway (Shahid et al. 2005).

SRY, a seemingly simple, beyond SRY single-exon gene discovered over a decade ago, given its pivotal role in mammalian biology. SRY encodes an HMG domain protein likely to act as a transcription factor, and in vitro studies of normal and mutant SRY (as produced in some human XY females) suggest that DNA binding, and the accompanying bending of the target DNA molecule, are important features of its function (Koopman 2001).

This study suggested that radiation exposure of cell phone for 30,60, and 90 min in 60 days in rat, caused the mutation in SRY gene. Two of three mutations (His38Glu and Pro76Thr) showed that the point mutation in SRY gene altered the synthesis of amino acid (histidine $>$ glutamine, and proline $>$ threonine), whereas one mutation has no change the translation of amino acid; Leusine102Leusine $(\underline{C T G}>\underline{T T G})$. Further study is needed to investigate the effect of novel mutation in SRY gene to sex determination, by separating the place of rat box container in different room to prevent the intervention of radiation effect.

\section{ACKNOWLEDGEMENTS}

The authors thank Directorate General of Research Reinforcement and Development, Ministry of Research Technology and Higher Education and LP2M for supporting the fund of the study, with Number contract DIPA-042.06.1.401516/2017.

\section{REFERENCES}

Behari J. 2010. Biological responses of mobile phone frequency exposure. Indian J Exp Biol 48 (10): 959-81

Canadian Nuclear Safety Commission. 2012. Introduction to radiation. Ottawa, Canada. http: //nuclearsafety.gc.ca/eng/pdfs/ReadingRoom/radiation/Introduction-to-Radiation-eng.pdf

Cellular Telecommunications Industry Association. 2003. Appendix A: Message from the CTIA (Cellular Telecommunications \& Internet Association) to all users of mobile phones.https: //fccid.io/GMLRH14/Users-Manual/Manual-final-2-309518.pdf

Chaney JL, Clark PL. 2015. Roles for Synonymous Codon Usage in Protein Biogenesis. Annu Rev Biophys 44: 143-66.

Chamary JV, Parmley JL, Hurst LD. 2006. Hearing silence: non-neutral evolution at synonymous sites in mammals. Nat Rev Genet. 7 (2): 98108.

d'Ambrosio G1, Massa R, Scarfi MR, Zeni O. 2002. Cytogenetic damage in human lymphocytes following GMSK phase modulated microwave exposure. Bioelectromagnetics 23 (1): 7-13. PMID: 11793401.

Fahraeus R, Marin M, Olivares-Illana V. 2015. Whisper mutations: Cryptic messages within the genetic code. Oncogene 35: 3753-3759.

Goodman MF, Bents FD, Tijerina L, Wierwille W, Lerner N, Benel D. 1999. An Investigation of the Safety Implications of Wireless Communication in Vehicles. Report Summary. US Department of Transportation Electronic Publication, Washington DC.

Hawkins JR, Taylor A, Berta P, Levilliers J, Van der Auwera B, Goodfellow PN. 1992. Mutational analysis of SRY: nonsense and missense mutations in XY sex reversal. Hum Genet 88: 471-474. 
ITU [International Telecommunication Union]. 2010. Measuring the Information Society. International Telecommunication Union, Geneva, Switzerland

Kato T, Miyata K, Sonobe M, Yamashita S, Tamano M, Miura K, Kanai Y, Miyamoto S, Sakuma T, Yamamoto T, Inui M, Kikusui T, Asahara H, Takada S. 2013. Production of Sry knockout mouse using TALEN via oocyte injection. Sci Rep 3: 3136. DOI: 10.1038/srep03136.

Knower KC, Kelly S, Ludbrook LM, Bagheri-Fam S, Sim H, Bernard P, Sekido R, Lovell-Badge R, Harley VR. 2011. Failure of SOX9 Regulation in 46XY Disorders of Sex Development with SRY, SOX9 and SF1 Mutations PLoS One; 6 (3): e17751. DOI: 10.1371/journal.pone.0017751. PMCID: PMC3055899.

Koopman P, Gubbay J, Vivian N, Goodfellow P, Lovell-Badge R. 1991. Male development of chromosomally female mice transgenic for Sry. Nature. 351 (6322): 117-21. DOI: 10.1038/351117a0

Koopman P. 2001. The genetics and biology of vertebrate sex determination (Meeting Review). Cell 105 (7): 843-847.

Mashevich M, Folkman D, Kesar A, Barbul A, Korenstein R, Jerby E, Avivi L. 2003. Exposure of human peripheral blood lymphocytes to electromagnetic fields associated with cellular phones leads to chromosomal instability. Bioelectromagnetics 24 (2): 82-90.

Phillips NB, Jancso-Radek A, Ittah V, Singh R, Chan G, Haas E, Weiss MA. 2006. SRY and human sex determination: the basic tail of the HMG box functions as a kinetic clamp to augment DNA bending. J Mol Biol 358 (1): 172-192.

Shahid M, Dhillon VS, Aslam M, Husain SA. 2005. Three New Novel Point Mutations Localized within and Downstream of High-Mobility Group-box Region in SRY Gene in Three Indian Females with Turner Syndrome. J Clinical Endocrinol Metabolism 90 (4): 2429-2435.

Sander R, Brinkmann J, Kühne B. 1982. Laboratory studies on animals and human beings exposed to $50 \mathrm{~Hz}$ electric and magnetic fields.
CIGRE, International Congress on Large High Voltage Electric Systems, Paris, 1-9 September; CIGRE Paper 36-01.

Sauna ZE, Kimchi-Sarfaty C, Ambudkar SV, Gottesman MM. 2007a. Silent polymorphisms speak: how they affect pharmacogenomics and the treatment of cancer. Cancer Res 67 (20): 9609-9612.

Sauna ZE, Kimchi-Sarfaty C, Ambudkar SV, Gottesman MM. 2007b. The sounds of silence: Synonymous mutations affect function. Pharmacogenomics 8 (6): 527-532.

Sauna ZE, Kimchi-Sarfaty C. 2011. Understanding the contribution of synonymous mutations to human disease. Nat Rev Genet 12 (10): 683-691.

Swamardika IBA. 2009. Effects of electromagnetic wave to human health (Review). Teknologi Elektro 8: 106-109.

Sykes PJ, McCallum BD, Bangay MJ, Hooker AM, Morley AA. 2001. Effect of exposure to $900 \mathrm{MHz}$ radiofrequency radiation on intrachromosomal recombination in pKZ1 mice. Radiat Res 156: 495502.

Talib SH, Patil P, Nikam P. 2010. Mobile phone and health hazards. J Indian Acad Clin Med 11 (3): 212-219.

Tice RR, Hook GG, Donner M, McRee DI, Guy AW. 2002. Genotoxicity of radiofrequency signals. I. Investigation of DNA damage and micronuclei induction in cultured human blood cells. Bioelectromagnetics 23 (2): 113-126.

Uddin ASMI, Ferdous J. 2005. Radiation exposure of cell phones and its impact on human health - a case study in South Asia (Bangladesh) and some recommendations. J Theor Appl Inform Technol 19 (1): 1521.

WHO. 2014. Electromagnetic fields and public health: mobile phones. Geneva, Switzerland. 